\title{
The Teachers' Preparation for the Work with Deviancy-Prone Students
}

\author{
Olesya V. Babenko ${ }^{1}$ \\ ${ }^{1}$ Kazan (Volga Region) Federal University, Kazan, Russia \\ Correspondence: Olesya Vladimirovna Babenko, Kazan (Volga Region) Federal University, Kremlyovskaya \\ Street 18, Kazan 4201008, Russia. E-mail: ladyboss81@mail.ru
}

Received: April 14, 2015 Accepted: April 20, 2015 Online Published: April 27, 2015

doi:10.5539/jsd.v8n4p95

URL: http://dx.doi.org/10.5539/jsd.v8n4p95

\begin{abstract}
The problem investigated sounds acute as long as any teacher can meet a necessity to work with different categories of students including young men and ladies who are at war with rules and regulations, and do not want to put up with typical social behaviour. The article aims at defining deviant behaviour as a studying discipline violation, which can become a harsh obstacle for the teacher's attempts to construct a usual architecture of a lesson. It also reveals a set of psychological-and-pedagogical conditions which are seen as capable of overcoming students' deviant behaviour. The experiment underlining the effectiveness level of the complex (set) suggested has become a mainstream investigation method of this problem and heads for a constructive work with risk-prone students (prone to deviant behaviour). Following a step-by-step prevention of students' deviant behaviour, implementing preventive pedagogics and deviantology into courses of further promotion for teachers, constructing theatre studios for risk-prone students - all this can set up a healthy atmosphere in a students' group and become a strong basis of preventive knowledge for the teacher. The article materials can be useful while organizing the teacher's psychological-and-pedagogical work (especially for beginning teachers) with a collective of risk-prone, deviant-behaving students - the students who tend to ruin the studying discipline systematically.
\end{abstract}

Keywords: deviancy-prone students, teachers' preparation for the work with deviancy-prone students, a set of psychological-and-pedagogical conditions conducive to overcoming students' deviant behavior, deviancy-resistant (preventive) work with students, deviation signs

\section{Introduction}

\subsection{Problem Acute}

Our investigation is connected with frequent cases of students' deviant behaviour: the behaviour characterized by negative deviations from commonly accepted (social) norms in society - the norms which have been going through numerous generations' experience. It reveals discipline discipline-violating behaviour (constant comings late, a disrespectful attitude to teachers, peers; hometask ignoring, a low level of studying progress and flopping at sessions, etc.) which can breed other people's disapproval and even social de-adaptation.

Teachers often turn out to be absolutely not ready for students' deviation-prone behaviour. An unprepaired teacher may find it challenging to overcome the following consequencies of deviation: the worsening of the moral-and-psychological climate in a group / sub-group (an increase of conflictive situations, aggressive and / or depressive behaviour forms, saying no to homework, daily time-table violation (getting late without further apologizing, rude provocative behaviour), a studying motivation decrease down to a critical level (when the matter of dropping out of university comes the matter of vital importance, etc.). Moreover, if this kind of student is an authority for his / her peers, there is a danger of the whole group's taking his / her scale of values.

Therefore, teachers should be able to spotting students' deviant behaviour, be attentive to risk-prone students and be ready to react properly in order to neutralize negative effects of this behaviour with students.

\subsection{The Signs of Deviant Behaviour, Its Basic Features}

How can we single out deviancy-prone students in a group? We have studied and systemized behaviour and psychological-and-emotional signs which can let us refer this or that student to the group of risk:

1) psychological-and-emotional, typical (Afanas'yev, 1995): 
a) addictions (alcohol, drug, game, sometimes a tattoo cult, etc.) and provocative behaviour (negativism demonstration, pushing peers towards beyond-the-discipline deeds, disrespectful attitude to teachers, behind-the-due-date task fulfilling, shabby looks, attacking positive leaders, laziness, the lack of good up-bringing, aiming at forming a group of like-minded people, etc.);

б) an inclination for distorted forms of behaviour and self-affirmation (with "strong" leadership-aiming students): a high level of aggression, egoism, aiming at ruining rules, absence of subordination, critical attitude to any task given (especially homework), an I-do-not-care attitude to things, impatient attitude to any kind of critics (any other style of communication, thinking), an inclination for distorted forms of behaviour, cursing, physical attacks, idleness, inability for self-critics and analysis of your behaviour, accepting discipline as something negative and not needed, high level of offensiveness, humiliation of others, egoistic attitude to others, taking your actions as the only right ones, high self-esteem, non-flexibility, stubbornness, trick-making. Weak deviants prone to submittance demonstrate nervousness, evil-thinking nature, introvertive type of character, offensiveness, low level of stress-resistance, infantilism, emotional instability, being moody, suicidal or depressive moods or ideas, low self-esteem, too vulnerable a nature, social inmaturity, conformity, loneliness, possible feeble body-build, "travelling" eyes, etc.

2) nervous disorders, deviations (Volkov, 2004)

a) development hold-up (getting behind from age-norms in physical, intellectual, social respect, fixed ideas, phobias, low self-esteem (as a consequence of childhood traumas, tragical events; possible physical disabilities, etc))

б) health status and appearance (drug- or alcohol-addiction in the past, previous life-threatening diseases, scruffy looks, certain kinds of hairstyle and other signs showing attraction to informal groups (some kinds of piercing, tattooing) signs of anorexia or bulimia)

в) sexual deviations (early sexual experience, multi-partner relationships, homosexualism, etc).

3) low intellectual communication level (Beznosov, 2007):

a) using prison-slang in speech, cursings. Admiration of criminals, listening to non-censored content music, poor vocabulary, inability to explain shortly and clearly, analyze and synthesize information; vulgar humour, demonstrating distorted life-values, instable mentality and life-position, argumentative nature, inclination for ultra-nationalism and / or betrayal.

б) low motivation for studies. Weak social skills, despise towards sports and studying well, highly demanding attitude to others, excluding yourself, etc.

4) genetic, social, retrospective (students from socially instable families, drug- and alcohol-addicts' children or parents with psychiatric deviations, problems with the police, army joining disapproval. Or on the contrary they can come from wealthy families and boast on their background and rich parents, people who do not know the word "no") (Koen, 1998)

5) in some cases regional, national sign (a special attention should be drawn to some students from the Far East, Middle Asia, Northern Caucasus, Volga region, southern parts of Russia, Pre-Ural regions - the regions with statistically higher levels of drug-addiction. Besides, some nations show hot-tempered nature more often than some others) (Kudryavtzev, 2010)

6) student's communication and interests circle (sometimes certain types of music, free time activities can tell a lot about a person than any kind of interview. Some students whose parents take a top-position in society, should also be under special attention because they can act cunningly, without attracting attention).

\subsection{Explore the Importance of the Problem}

Due to difficulties of working with risk-prone students, prevention comes the rescuer and neutralizer of possible deviant behaviour forms at the university.

The main problem is that teachers are not taught to deal with non-discipline behaviour. We study teaching methodology, brush up the knowledge of our subject, psychology, however, have little conception about working with students who keep on ruining your lesson systematically. Prevention knowledge seems to be the only way out.

Prevention of discipline violation is considered as a professional organization of measures based on a set of psychological-and-pedagogical conditions aimed at optimizing the quality of psycho-pedagogical interaction 
between university teachers and students, and at localizing, minimizing andneutralizing deviant behaviour among students.

\subsection{Status of a Problem}

The following scientists dedicated a wide range of works towards stusying prevention work against deviations: V. Aphanas'ev (1995), S.P. Beznosov (2007), A.Coen (1998), B.T. Likhachyov (1992), U.M. Kudryavtzev (2010) and more.

The analysis of the authors' works enabled us to see the lack of system in data. We have gathered the data together in order to get the puzzle on deviation behaviour prevention.

\section{Materials and Methods}

\subsection{Criteria and Indicators of Preventive Work Effectiveness at University}

Criteria and estimation indicators of pedagogical activity on the preventive work with the risk-prone group in a higher educational establishment can help to discover the degree of teachers' readiness for the work with deviancy-prone students:

1) establishing and educative (the presence of preventive disciplines in the working program of a university, having a strong scientific and methodical basis of diagnostics and prognostics with an easy accessibility for teachers, underlining equal studying responsibility of every student and making sure students remember it).

2) diagnostic-and-prognostic (providing students with a personality diagnostic methodic to independently define potential discipline breakers and positive-to-studies young men and ladies).

3) estimation-and-result (the estimation of teachers' ability to scan preventive activity at university and define its level of effectiveness, analysis of motives of discipline violation cases).

In order to define the system functionality of teachers' readiness to deal with "about-to-do-something-wrong" groups, we find it essential to measure the readiness degree on levels and indicators among which we can name:

a) high (the teacher is fully acquainted with a set of psychological-and-pedagogical knowledge and skills, can independently plan his / her preventive work, is top-motivated, is able to set up aims and tasks of diagnostics, reveals a creative attitude to the process, interacts with colleagues, parents, etc.)

б) satisfactory (an optimal level of knowledge, good planning skills, however without regularity and self-motivation).

в) unsatisfactory (lack of organizing and planning skills, fragmentary preventive work, absence of creativity and individual approach, low motivation level).

Having interviewed practice-oriented teachers and psychologists, we arrived at the conclusion about the impossibility of finding a "universal" criterion for scanning the discipline level at a university, because it would build a one-way narrow-mindedness and would deprive the process of its individuality. Only one criterion might provoke the appearance of teachers' similar reports and beautiful numbers in statistics and give a wrong picture of the discipline status quo at a university.

\subsection{A Set of Psychological-and-Pedagogical Conditions on Students' Deviant Behaviour Overcoming}

The above mentioned fact about fake reports has become a stimulus for developing a set of criteria and indicators capable of showing an objective picture of preventive work with risk-prone and not-loving-discipline students.

In accordance with our investigation aim, the task was to measure and prove the effectiveness of the set of conditions of teachers' readiness for preventive work with deviancy-prone students. As a complex social and psychological-and-pedagogical phenomenon, the process of teachers' training at universities has its own structural elements, inner bonds and contradictions.

The first psychological-and-pedagogical condition - an implementation of methods of step-by-step discipline violation prevention is aimed at revealing "difficult" students. We can prove that studying preventive disciplines (preventive pedagogics and psychology (24h.) and deviantology (16h.)) within the university program should require a certain level of teachers' competence and regularity of this activity practicing.

According to our opinion, the improvement of teachers' training for the work with a risk-prone group is a secret of successful management of a student group, the group's emotional status monitoring.

The chief idea of the programme can become training teachers to follow a preventive scheme step-by-step and within narrow time-limits. The author finds it important to underline that the first two preventive steps (studying retrospective and diagnostics) are preliminary and take 1 or 2 months. The next three steps (analysis, interaction, 
optimization analysis, correction work) are reconstructive stages and take from 2 to 6 months. We would like to underline - approximately, because the degree of challenge is different in every out-of-discipline situation as long as we talk about people with a special inner world, non-typical mentality, individual perception of preventive actions and different reaction speed.

Let us define the chief aim of our pedagogical experiment: to prove that a constructive realization of a step-by-step preventive activity can reach the maximum of its effectiveness on condition that deviancy-prevention disciplines are included in university programme not just as extra-curricular studies.

For making the experiment two teachers' groups were formed (control group (further appears as CG) - 60 people: 2 subgroups per 30 people each) and experimental group (EG) made of 60 people with 31 participants in each subgroup).

The starting point of our experiment was the beginning of the training process of EG on the promotion programme "Professional psychology" (Kazan National Research Technological University). The final point was presenting diploma works on the programme. Inside the programme the author develops the contents of the course of deviantology and preventive pedagogics, teaches them.

At both starting and final points of teaching EG, all participants were interviewed in order to estimate the self-esteem dynamics of readiness of both $\mathrm{CG}$ and EG and realize the level of their readiness for preventive activity.

During the testing additional explanations were given and individual assistance took place. Throughout the experiment methods of observation, narration analysis, discussion, debating were used.

Control knowledge testing of teachers of CG and EG took place during EG teachers' graduation week (on the program "Professional psychology").

The standard studying process (preventive discipline-free) showed insignificant alterations in self-esteem dynamics of preventive activity readiness of CG teachers at both stages: at the beginning of the training and at the end as well Judging from the CG teachers' sayings, we came to the conclusion that they do not feel confident about overcoming students' deviant behaviour. Moreover, some of them showed little motivation towards the problem raised and claimed the problem of deviant behaviour should be discussed in families, not at universities. Reprimands, warnings, informing families, exemption from a university are thought to be the only methods of typical punishment for discipline-breakers. A diagnostic stage is believed to be sufficient for this level of education. Besides, a few interviewers mentioned we should act by intuition only (Figure 1).

points

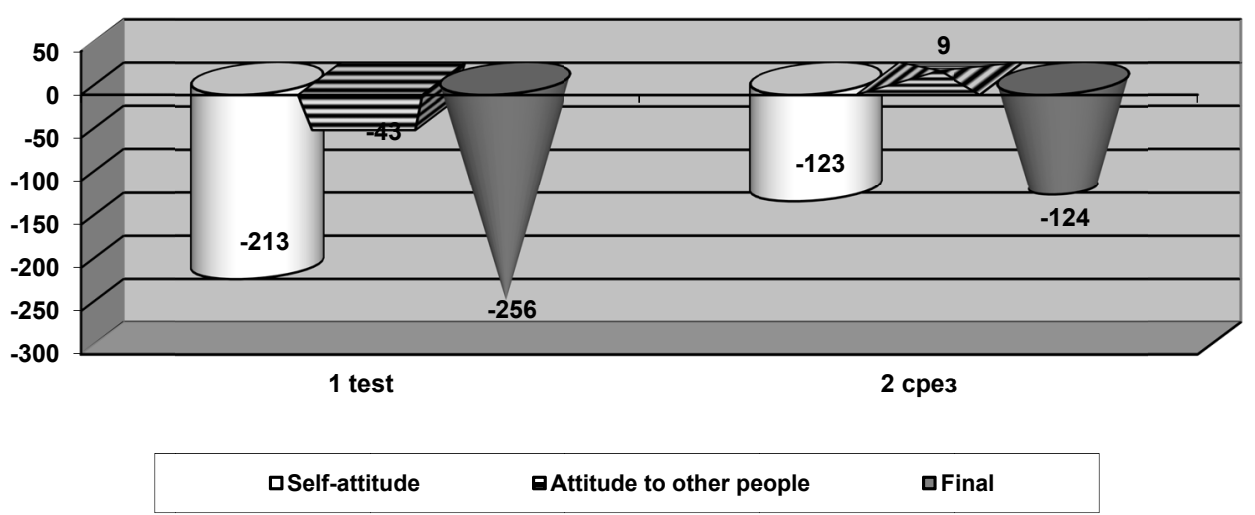

Figure 1. Self-esteem dynamics of teahers' readiness for preventive work in standard conditions (on final interviewings of 60 teachers of $\mathrm{CG}$, in points)

And now let us draw your attention to the results of starting and final interviewings of EG, so that you could see a vivid difference (Figure 2).

points 


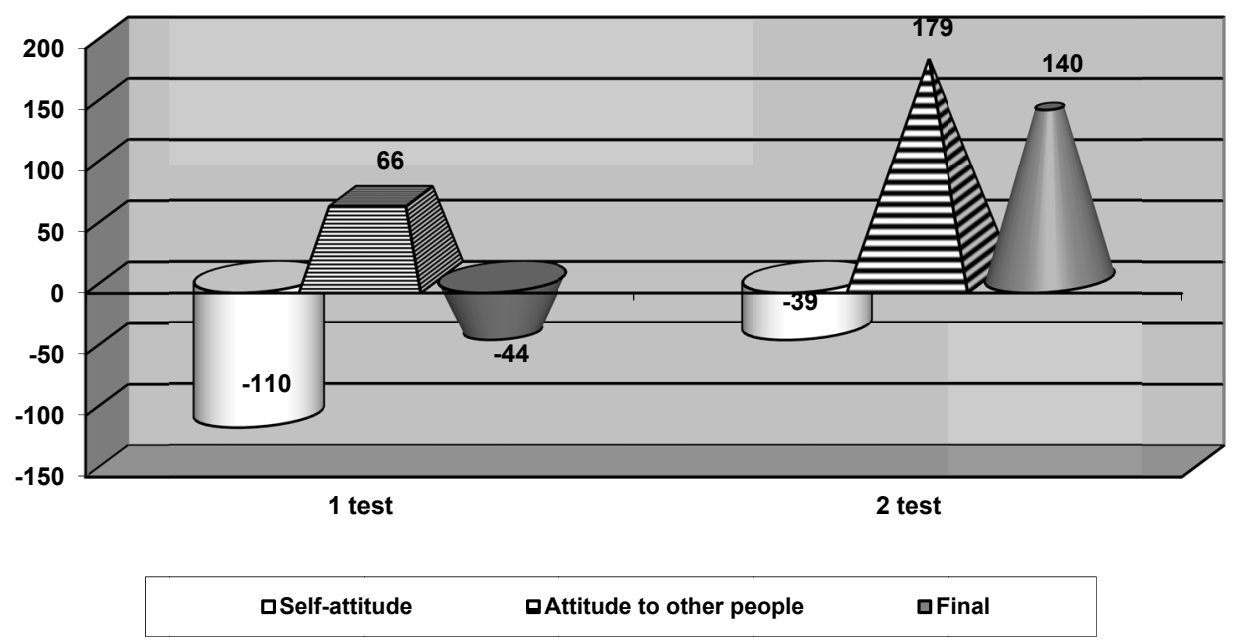

Figure 2. Self-esteem dynamics of teahers' readiness for preventive work after extra-discipline training on the programme "Professional psychology" (on the final interviewing of 62 EG teachers, in points)

Our interview results make it possible to see positive dynamics in EG teachers' self-esteem in terms of the EG readiness for the preventive work with deviancy-prone students - in comparison with the CG testing results. It is necessary to note the change in the attitude towards prevention work for the better - as well as the formation of personal willingness to participate in conflict avoiding within your student group. The EG teachers' confidence in their own abilities of working with deviant behaviour has definitely increased - we can follow this idea on the basis of individual-and-group testing. They have realized that even almost adult personalities can be influenced in the positive way provided a special communication environment is organized. The data received enable us to conclude about the value the promotion career programme can give, the data concerning preventive activity. The EG teachers received a vivid advantage in relation to deviantology knowledge, preventive pedagogics and psychology, having totally understood the importance of their presence in university curriculum. (Figure 3).

points

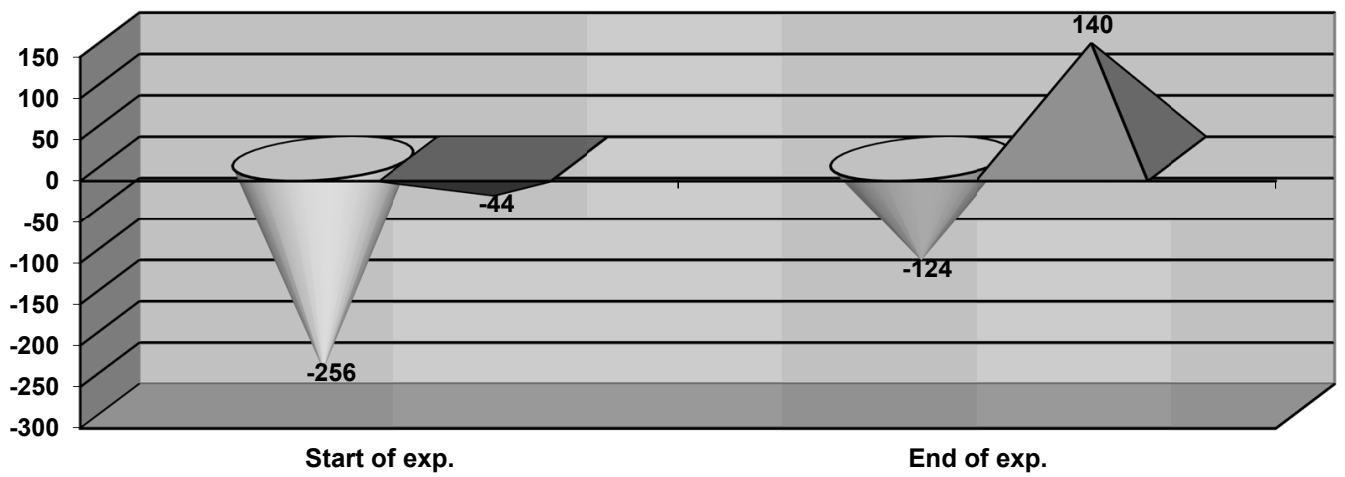

口CG 口EG

Figure 3. Comparative characteristics of self-esteem alteration in terms of the CG and EG teachers' readiness for preventive activity as the result of extra training on the program "Professional psychology" (in points)

By all means, the answer level of the EG might have been even higher if the teachers' training period on preventive work was longer (table 1). 
Table 1. The dynamics of levels of the CG and EG teachers' readiness for preventive activity during studying work (in absolute meanings)

\begin{tabular}{lllll}
\hline \multirow{2}{*}{ Levels } & $\begin{array}{l}\text { Control group } \\
(60 \text { people })\end{array}$ & & Experimental group (62 people) \\
\cline { 2 - 5 } & Exp.start & Exp.end & Exp.start & Exp.end \\
\hline High & - & 4 & - & 7 \\
Medium & 11 & 21 & 10 & 29 \\
Low & 49 & 35 & 52 & 26 \\
\hline
\end{tabular}

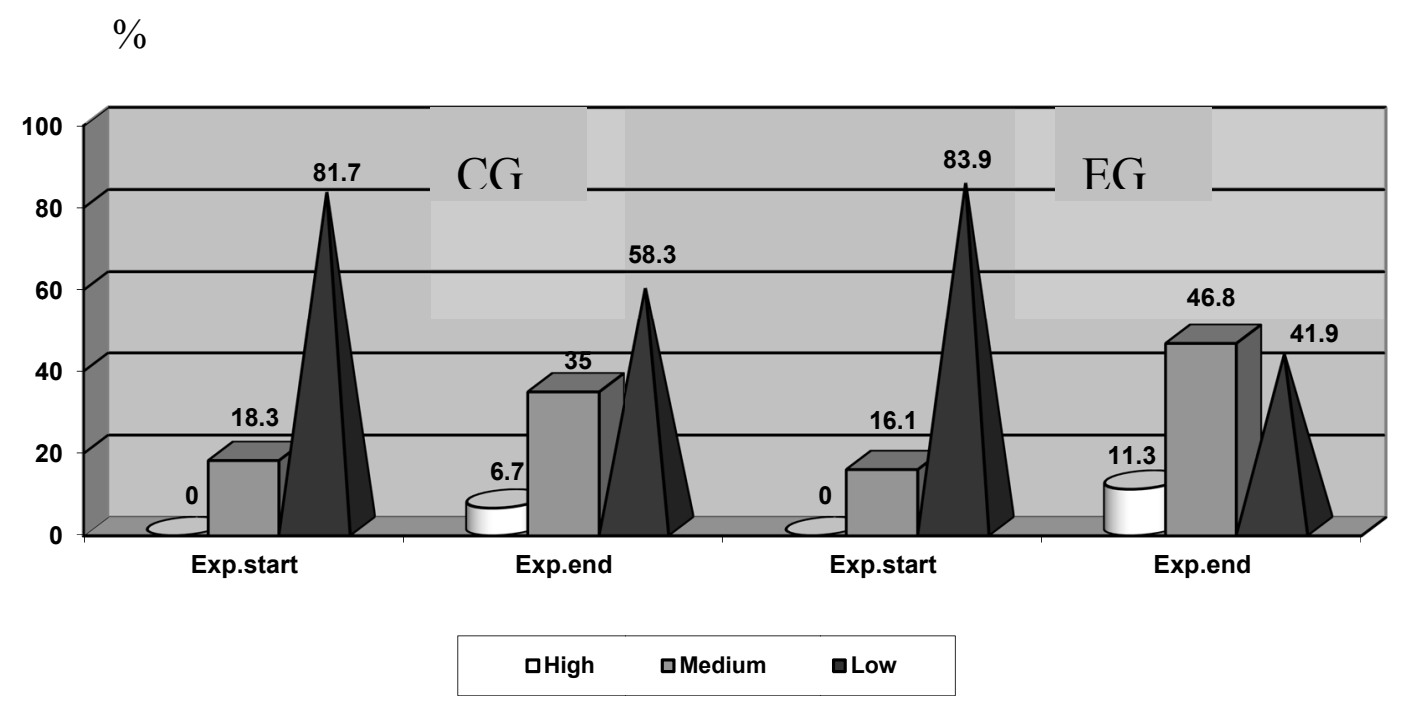

Figure 4. Dynamics of levels of the CG and EG teachers' readiness for preventive work during the educative process (in \%)

We can highlight the received data about the levels of the CG and EG teachers' readiness for preventive work during the educative process in the following graph (Figure 4).

The second psychological-and-pedagogical condition of university teachers' training for the preventive work with potential discipline-breakers, sounds like creating a diagnostic-and-prognostic basis of an early detecting and further correction of possible beyond-the-discipline behaviour and defining criteria and levels of teachers' preventive training.

The investigation was a complex character of diagnostic and prognostic activity which relied on the integrity of five experimental disciplines of additional training programme of Kazan National Research Technological University "Professional psychology": preventive psychology, age psychology, psychology of extreme situations, deviantology (psychology of deviant behaviour). The contents of each of these disciplines is conducive to the main aim of this stage of our investigation: to analyze the EG teachers' skills of a correct step-by-step diagnosting of their students.

During the whole experimental work we were organizing current tests for making a true-to-fact picture of the EG's positive dynamics.

Teaching the EG the rules of correct diagnostics of your collective to define students with both positive and negative attitudes to studies, came across with certain difficulties:

1) $4 \%$ of EG marked some kind of absent-mindedness and inconfidence saying that discipline violations may flow without being noticed initially.

2 ) about $2 \%$ of teachers referred to diagnostic difficulties and incapability of coordinating the forces of the whole collective into fighting with negative situations as well as systemizing the received data. 
The author's help in this case was verbal (advice, group and individual discussions) and methodical (choosing proper diagnostic tests including the ones developed by the author). In the first case (with latent forms of deviant behaviour) we have arrived at the idea that with possible difficulties like these, we should do the following:

1) when our suspicion falls onto latent forms of deviant behaviour that might be present within our student group (when we see violations but do not know a violator), we have to set up "observation posts" of like-minded studies-oriented people of 2-4 who could scan the collective and put down any changes.

2) raise the frequency of testing to define the level of aggression and social adaptation, probably attract university medical staff for help (out-of-plan check-ups).

3) at current cathedra meetings we should give the data about violations and set up an expert commission.

4) maintain connections with parents if possible (to understand inner motives).

The third psychological-and-pedagogical condition of optimizing preventive training could be the work of theatre and literature studios - like the one that exists in Kazan Higher Military Command College and has already proved its effectiveness. These studios could become a panacea for deviancy-prone students.

Why should it work? The answer is simple: a student's personal involvement in literature and cultural projects are able to distract him / her from deviancy and show alternatives of expressing yourself through hobbies.

In general, "difficult" students are young guys and ladies with a distorted vision of the word and values which they take as norm. They are also students feeling lonely and misunderstood, who do not know they can be talented or at least try something new. Regular involvement in projects of literature and culture in the foreground can get deviant students busy with something really creative and useful and tends to have good class-building abilities.

Professor Gerasimov V.N. has always underlined that making certain conditions for creative realization of a personality can make people believe in their creative abilities and open their talents, focus attention on traditional values or even become the studio leader (Komarova, 1998).

The library in Kazan Higher Military Command College can boast having such a studio for more than 10 years running. The article author has been participating in the studio work and can conclude that art can make wonders and really distract people from deviant behaviour into traditional one, oriented at commonly accepted values. The nuclei of the group is made of military students of high motivation as long as those who has problems with studies. Every participant has a strong chance to be the studio leader for at least three months, so that everyone could have a chance to feel the level of responsibility for the work of other people in the group.

The idea of the studio setting up belongs to librarians after making literature evenings and performances which involved the work of local talents and as an experiment, 5 military students of top motivation for studies and 5 low-motivated guys. The deputy director of the College confirmed the studio work on a regular basis because the results were stunning: 5 students with discipline problems liked being creatively busy and showed better studying results, and even invited friends to help.

Being one of the studio leaders and programme-makers, the author sees the studio main goals like this:

1) working out the concept and contents of the literature and theatre studio in order to correct the behaviour of a risk-prone group by means of art;

2) setting up a collective of like-minded people with different background and mentality, ethnical and religious directions in order to develop a person's creativity and initiativity, self-expression and emotional feedback, to enrich a person's inner world spiritually and show alternatives of behaviour. All are equal in front of art.

Together with studio participants we have worked out a set of regulations of our studio "My honour!":

1) breed creativity in yourself, stimulate other participants' creativity and help each other in a common matter

2) try something new and do not be afraid of taking new tasks for fulfilling - may be you will you're your new talent

3) learn to achieve your and the group's goal in spite of possible mistakes

4) respect your speech and avoid rubbish words like jargonisms. Cursing is tabooed and punished (role deprivation)

5) show respectful attitude to all participants, not only to the leader, etc.

The tasks of the preventive art work have become the following: 
1) change depressive and aggressive moods into creative and busy ones, discussing the range of responsibilities and underlining each participant's important role in a common matter

2) divide obligations of the risk-prone group at a collective meeting taking their individual abilities and wishes into account

3) read "The letters about the good and fine" by D.S. Likhachyov with further analysis and discussion. An active part in discussions with your own opinion-expressing is an obligatory condition. The participants learn to listen to each other and argue in a civilized way. The main principle here - be able to work with your partner trying to walk in his shoes. Emotional development takes place along with reading motivation

4) hold weekly meetings to sum up the studio productivity work, forming common traditions (celebrating successful performances with tea-parties, choosing "The month actor", script and costumes discussing, etc.)

5) confirm the programme at a meeting, appoint a weekly monitor (out of students with deviant problems)

6) maintain the atmosphere of creativity, mutual support, development of healthy competitiveness and initiativity, strictly denying attempts of deviant behaviour and punish with absence of roles and routine studio work for a week.

The studio programme is not limited with regular evenings dedicated to jubilees of outstanding Russian writers and military leaders, it also shows real performances of civil contents which could be interesting for the participants' officers' families as well.

\section{Results}

For a sound preventive work against deviant behaviour among students regular teachers' training, enough time should be devoted to learning preventive sciences (like deviantology and psychology of extreme situations), a better student enrolling should be held (with having data about a person's background, f.e.), pedagogical strictness should go side by side with frank conversations on acutest topics, surveillance cameras should be installed, etc.

University teachers should be well-informed in terms of preventive knowledge, so that they could cope with possible coming up problems independently. There exists a step-by-step scheme of preventive work approved by numerous investigations and years of practice.

A further investigation of this kind of work should go the following ways: optimization of teachers' training on the problems of deviancy, working out conditions of cultural and after-studies work with deviancy-prone students, building the system of deviation understanding within the program of higher educational establishments.

In addition, in many cases deviant behaviour can be cured by theatre studios organized in higher educational establishments open a completely new range of possibilities in teachers' preventive work. It comes a perfect distraction from some students' negative ideas about discipline breaking, which has been proved experimentally.

The complex of the above mentioned psychological-and-pedagogical conditions can be considered as a reliable medium of teachers' preventive work with students' deviations in behaviour.

\section{Discussions}

Some aspects of the problem studied were reviewed in last centuries as well - what tells about its "eternity": both in the time of tzars and in Soviet time the problems of discipline were put forward as serious and acute. The approaches were different: basically one-way authoritative, rigid, not really human-oriented.

We can single out the following publications:

Utlik E.P. (1993), Volkov I. (2004) show discipline as a house basis.

Afanas'yev V. (1995), Beznosov S.P. (2007) describe psychological sides of the discipline and the ways of its keeping through the prism of a teacher's and student's personalities.

Kudryavtzev U.M. (2010), Barkhayev B.P. (2007) discover the motives of deviant behaviour and the ways of dealing with it.

In connection with all this there comes a necessity to generalize all the data into one complex (set). 


\section{Conclusion}

The set of psychological-and-pedagogical conditions on overcoming and prevention of deviant behaviour suggested in the article, can become a large-scale work of teachers' training on preventive work with risk-prone students.

The set is of high value for specialists who are willing to broaden their horizons and increase their readiness for typical studying situations - deviant behaviour in class and out of it.

University can include extra disciplines based on the knowledge about deviant behaviour both for students and teachers (as promotion career courses) in order to arm them with additional competences of not only detecting deviations (and latent ones!), but dealing with them skillfully enough.

Moreover, every teacher - no matter what subject he / she teaches - should consider it a matter of honour to learn how to build relationship with the most disciplinary-fragile group of students: with discipline-breakers. Teachers have a really human-oriented profession and have to be good psychologists as well as good teachers. Discipline helps to concentrate people on something important. Discipline-breakers hate discipline and ruin it, which makes us, teachers nervous and upset. Authoritarian methods work, but do not a desired effect. The only way out is seen in collecting knowledge about this special category of people who think it normal to crash rules and regulations, in looking for effective discipline-saving solutions.

We have proved the possibilities of overcoming deviant behaviour by setting up literature-and-theatre studios with special aims of preventive work. This work is not one-day or one-week, we should be patient enough - it takes a while for the bird to make a nest. But the result can bring so long-awaited changes, when a person opens a new talent in himself / herself and forgets about protesting for the sake of protesting.

Deviant behaviour cannot be killed, but can be cured - if only all teachers tried hard to get the knowledge they lack in dealing with the phenomenon.

\section{Acknowledgments}

The work is performed according to the Russian Government Program of Competitive Growth of Kazan Federal University

\section{References}

Adler, S. (1996). Personality and work behaviour: Exploring the linkages. Applied Psychology, 45(3). http://dx.doi.org/10.1111/j.1464-0597.1996.tb00765.x

Afanas'yev, V., \& Gilinski, Ya. (1995). Deviantnoye povedeniye i sotzial'ni kontrol' v usloviyah krizisa Rossiyskogo obshestva. Sankt Peterburg, 55-106.

Babenko, O. V. (2012). Podgotovka kursantov voyennyh vuzov k rabote s voyennosluzhashchimi, sklonnymi k neustavnym vzaimootnosheniyam (Dissertation).

Barkhayev, B. P. (2007). Pedagogicheskaya psikhologiya. Sankt Peterburg, Piter.

Beznosov, S. P. (2007). Professional'naya deformatziya lichnosti. Sankt Peterburg: Rech.

Koen, A. (1998). Otklonyayushcheesya povedeniye I kontrol' za nim. Amerikanskaya sotziologiya: perspektivy, problemy, metody. Moscow: Progress.

Kudryavtzev, U. M. (2010). Podgotovka prepodavateley $k$ rabote s kursantami, sklonnymi $k$ deviantnomu povedeniyu. Kazan.

Likhachyov, B. T. (1992). Pedagogika. Kurs lektziy. Moscow: Uchebnoye posobiye.

Utlik, E. P. (1993). Psikhologicheskiye problemy distzipliny. Moscow, Russia.

Velikiye mysli velikikh lyudei. Antologiya aforizma: v 3-h tomah. Ot Srednevekov'ya do Prosveshcheniya. (1998). V.2. Moscow: Ripol Klassik.

Volkov, I. (2004). Distziplina minus passivnost', 5, 39-42.

\section{Copyrights}

Copyright for this article is retained by the author(s), with first publication rights granted to the journal.

This is an open-access article distributed under the terms and conditions of the Creative Commons Attribution license (http://creativecommons.org/licenses/by/3.0/). 